\title{
PROBLEM SOLVING ABILITY AS A PREDICTOR OF MARITAL SATISFACTION AMONG MARRIED INDIVIDUALS IN SOUTH EAST, NIGERIA
}

\section{LILIAN C. OZOEMENA, SHUNAMIT, E. OGBUABOR, FLORENCE E. OTTA, ANGELA N. NWADIKE \& AGATHA U. NZEWUJI}

Department of Educational Foundations, University of Nigeria, Nsukka

\begin{abstract}
The general purpose of this study was to determine whether problem solving ability predict marital satisfaction among married individuals in South East Nigeria. A correlation survey research design was adopted for the study. The area of the study was South East Nigeria with focus on Anambra, Enugu and Imo States. The population was made up of 10, 533 married individuals. The sample consisted of 900 married individuals drawn using multi-stage sampling procedure. The following instruments were used in the study, Problem Solving Ability Questionnaire (PSAQ) and Marital Satisfaction Questionnaire (MSQ) and where subjected to face validation by three experts. The internal reliabilities were determined using Cronbach Alpha with reliability coefficient of 0.818 and 0.662 respectively. Regression analysis was used to answer research questions 1 -3. Hypotheses 1 were tested using simple linear regression and multi regression analysis, were use to test hypotheses 2 and 3. The result of the study indicated that there exists a weak relationship between marital satisfaction and problem solving ability. There was no relationship between problem solving ability and marital satisfaction. The level of Education and the gender of the respondents did not influence courtship and problem solving ability to significantly $(p>0.05)$ predict the amount of variation in marital satisfaction of married individuals in South East Nigeria. Based on the findings of the study, implications were highlighted and recommendation made, prominent among which is that the counsellors should organize seminars and workshop on problem solving ability and marital satisfaction for the youths and married individuals. Limitations as well as suggestions were also highlighted.

KEYWORDS: Problem Solving Ability; Marital Satisfaction; Married Individuals
\end{abstract}

Received: Jun 06, 2020; Accepted: Jun 26, 2020; Published: Aug 31, 2020; Paper Id.: IJMPERDJUN2020977

\section{INTRODUCTION}

Marital satisfaction is a form of marital bliss in which married individuals long and yearn for one another unfortunately, it appears that most families struggle to sustain peaceful living while some seen to be giving up to separation and divorce thereby creating a shattered marriage. Evidence from literature show $0.2 \%$ of men and $0.3 \%$ of women decide to end their marriage according to the national bureau of statistics [2018]. Therefore the researcher is of the view that so many married individuals are enduring their marriages and raising up substandard children that affect the society negatively. This ugly state of affairs has been widely attributed to many factors by largely to lack of problem solving ability that is prerequisite for marital satisfaction. Marriage has been defined by different authors in different ways based on both educational and cultural backgrounds. However, the concept of marriage can be principally seen as an institution in which ultimate inter personal relationship usually intimate and bond couples together. Hence, Haviland [2011] defines marriage as a socially or ritually recognized union or legal contract between spouses that establishes rights and obligations between themselves, their children, and their in-laws. This reveals therefore that marriage is often a formalized union legalized through church wedding and traditional marriage. 
The term marriage is an interesting concept that has attracted the attention of various scholars. Consequently, marriage as a concept has been viewed in several dimensions by various scholars. Maduka (2006) posited that marriage is an adventure because the two individuals that have agreed to cohabit are willing to take risks, test new ideas and experience new situations and that no matter how long the courtship has been, neither can boast of having studied and known all about the partner's dispositions and preferences. Hence, marriage provides an adventure playground for couples and their ability to adjust paves the way to a successful marriage. Marriage is a union between a man and a woman is intended to be a source of happiness, pleasure, compassion and love should typically provide a reliable means for satisfaction of sexual desires (Bagarozi, Bagarozi, Anderson \&Pollane, 2004). Marriage is the socially acceptable union between a man and a woman. It means the coming together of two totally different individuals as husband and wife in agreement to plan and set up their own family. This implies that marriage should be entered into by people who are not only mature in body frame, but physically, psychologically, emotionally, resilience and in reasoning.

Marriage is the first step towards starting a relationship among couples. Kaslow (2002) indicated that if two people share a good marriage, then starting a marital relationship and taking good care of it would not be a problem. The author reiterated that the opposite is true if the marriage is not built on a strong foundation. According to Egbo (2003), there are people who no longer view marriage as a means to personal fulfilment. According to the author, in the traditional olden days, marriage was viewed as the ultimate rite of passage for which a girl was prepared from a tender age. Justifying the above point, Njoku (2009) opined that in the olden days, marriage had a purpose and a structure. As such, it operated under a very organized system that was put in place so that if things fall apart, there was a way to pull it all back together again. In the words of Gottman (2004), marriage was ventured into for procreation, security and companionship among other social and psychological needs. Clearly, the fundamental reasons why people get married haven't changed with time but the approach definitely has lingered the issues of marital dysfunction. First, young men and women were prepared for it by the entire community. Everyone knew what was expected of them and if they fell short of these expectations for one reason or another, it will be reconciled. Again, the community was involved because marriage was about bringing people together rather than driving them apart. Subbo (2006) asserted that now, strangers meet, sometimes far away from home and decide that since they like each other, they can get married.As a result of the above highlighted issues, there is a newly wedded couple that do not have any clue about what they are doing together. If anyone tries to intervene, even wellmeaning friends or relatives, they are asked to get out and do not interfere.

In the past, marriage was the expected result at the end of the learning curve. It was an obligation that women undertook without question and things generally ran according to plan Kang and Taswal (2009). However, today couples have the freedom of choice, which means they can marry anyone any time they want-or not. They can choose to get along with the mother-in-law or not. Couples can choose to be submissive or forceful and not care about what the world thinks of them. Unfortunately, while freedom of choice is a good thing, it hasn't made marriage any better but rather cases of broken homes abound. The author concluded that if marriage in the modern world is to survive and to avoid the cases of marital dysfunction, people need to be more realistic and brutally honest with each other. This implies that such person may begin to behave as a marriageable person whose behaviour could appeal to men who are in search of a woman to marry.

There are various forms or types of marriage which include; monogamy, polygamy, polyandry and group marriage. According to Mulder (2009), "monogamy is a form of marriage in which one man marries a woman. It is the 
most common form of marriage found in societies around the world". Monogamy is believed to be as old as man. "It is universally practiced providing marital opportunity and satisfaction to all individuals. It promotes love and affection between husband and wife. It contributes to family peace, solidarity and happiness". Monogamous marriage is believed to be stable and long lasting. This is because it gives greater attention to the socialization of their children and the women enjoy better social status.

There are two types of monogamy; serial monogamy and straight monogamy. Serial monogamy allows individuals to remarry often on the death of the first spouse or after divorce but they cannot have more than one spouse at the same time. Straight monogamy does not allow remarriage of individuals.

Polygamy is a form of marriage in which one man marries more than one woman at a given time. It was a common practice in ancient civilizations. At currently it may be present in primitive tribes like Crow Indians, Baigas and Gonds of India. Polygamy is of two types; sororal polygamy and non-sororal polygamy. Sororal polygamy is a type of marriage in which the wives are invariably the sisters. It is often called sororate. It is usually observed in those tribes that pay a high bride price. Non-sororal polygamy is the opposite of sororal polygamy in which the wives are not related as sisters.

Polyandry is the marriage of one woman to several men. It is practiced among the Marquesan Islanders of Polynesia, the Bahama of Africa and tribes of Samoa. In India among the tribes of Tiyan, Toda, Kota, Khasa and LadakhiBota, polyandry is still prevalent. It is of two types, fraternal and non-fraternal polyandry. Fraternal polyandry is the type of marriage when several brothers share same wife. It is prevalent among the Todas in India. Non-fraternal polyandry is the type in which husbands need not be related. The wife goes to spend some time with each husband. So long as a woman lives with one of her husbands, the others have no claim over her. There is always the problem of determining biological paternity of the child. The children after the first few years are given the liberty to choose their parents for their permanent stay. The selected parent becomes the actual father of the children.

In this study, marriage could be perceived as a union of a man and woman as the case maybe, who have different perspectives but have become joined as one by the virtue of marriage relationship and they become married individuals.

According to (Nwobi, 2015) stated that married individuals are two individuals of different sex who has entered into a project with primary goals as sex satisfaction, security of companionship and economic security. Marriage is not an accidental affair. It is entered into consciously after the intending couples have taken time to come to know themselves better through a period of self-observation referred to as courtship. Married individuals is a union of a man and a woman who has agreed to leave together for mutual help, procreation and rearing of children and establishment of family (Mba, 2008). A married individual is a basic foundation of marriage where two opposite sex individuals live together with commitment. They form an economic unit and care for each other. They find their identity as importantly attached to each other (Oparaugo 2010). In the context of this study married individuals are two individuals who have accepted to share their love and affection as one body in marriage to give space for marital satisfaction.

The issue of marital satisfaction is often a source of major concern as it seems to be a major foundation of various marital problems. A lot of scholars have delved into the issue of marital satisfaction with the view to understanding the issue as well as finding ways of ensuring marital satisfaction among couples thus various definitions of the concept of marital satisfaction have emerged over the years. Also, various scholars "have used a variety of synonyms for marital 
satisfaction, including marital quality, marital success, adjustment, happiness, consensus, companionship, and integration" (Charisma test, 2006). For the author, marital satisfaction is a subjective evaluation of one's experience in their marriage. By subjective evaluation, it means that marital satisfaction can only be rated by each person in response to the question, how satisfied am I?.In their own view, Jose \&Alfons (2007) posited thatmarital satisfaction depicts a condition whereby husband and wife or a couple spend maximum time in their marital relationship living in harmony with little or no marital distress. In his own view, Maciver \& Dimkpa (2012) sees marital satisfaction as the attitude an individual has towards his or her own marital relationship. This attitude could be positive or negative depending on how beneficial or not the marriage is considered to be by each partner. The level of one's marital satisfaction cannot be determined by anyone else except the couples involved in a marriage union. A higher level of marital satisfaction according to Alder (2010) is seen as a measure of marital success. Espousing their own view, Emily and Todd (2015)stated that "marital satisfaction is a mental state that reflects the perceived benefits and costs of marriage to a particular person". The authors stated further that the more costs a marriage partner inflicts on a person, the less satisfied one generally is with the marriage and with the marriage partner. Similarly, the greater the perceived benefits are, the more satisfied one is with the marriage and with the marriage partner. This implies that marital satisfaction may be dependent on the extent and level to which spouses are willing to embrace each other's views, ideas, strengths and weaknesses in their various homes.In the context of this study, marital satisfaction is seen as the evaluation of harmonious and peaceful coexistence between husband and wife in their marriage within their various homes. This implies that the concept of marital satisfactionis used to describe the extent or level to which each marriage partner enjoys the marriage.

Homes provide care, protection, security (mental, moral among others) and fulfils other needs to sustain husbands and wives and to make the child fit in the society (Sunil, 2011). The author also asserted that many couples depend on the home for their levels of comfort, protection and peace. Unfortunately, irrespective of the vital functions of the home, it appears that many families still grapple with the challenges of coexisting whereby it seems that marital satisfaction is a mirage before them. This may be as result of the rate of misunderstanding, separation, broken homes and divorce cases among married couples especially in South East part of this country.

Many married individuals appear to have separated because of lack of marital satisfaction in their marriage. This separation is due to various factors like; inability of a partner to meet up with the expectations of their partners by embracing the views, ideas, strengths and weaknesses of their partners in their various homes. Wegar (2005), state that lack of understanding among couples is also identified as a factor contributing to lack of marital satisfaction among couples. Then one begins to wonder if problem solving ability has anything to do in improving their marital satisfaction or not among married individual.

Marital dissatisfaction arises and may escalate to divorce in some cases because some individuals lack the capacity to solve problems. This means that problem-solving ability is a veritable tool in creating mutual interpersonal relationship among individuals, including married individuals. According to Dewald (2010) problem solving ability is a process of identification, interpretation of the problem, consideration of possible alternatives, selection of the solution, implementation of possible alternatives, decision and evaluation of result. In a related view, Wallance and Clark (2014) listed the problem solving process as identifying the problem, interpreting the problem, listing the alternatives, selecting the best solution, implementing the decision and evaluating the consequences. In other words, problem solving ability can be defined as a higher order cognitive process geared towards achieving a goal when no solution seems obvious to the 
problem solver. The ultimate goal of problem solving is to overcome obstacles and find a solution that best resolves the issue at hand.

Problem solving ability as applied to marriage is the process whereby couples settle their marital problems through positive reactions to each other's view (Mitchell, 2012). The author stressed further that problem- solving abilities can increase the success and sharing experiences of couples and can enable them to overcome failures. Similarly, problem solving ability could be seen as individuals' skill to make positive changes in their relationships, to overcome the obstacles which they encountered in the past (Erus, 2016). The author reiterated that "couples should be able to enter into positive communications, make positive decisions, share resolutions, organize their plans and carry them out and share their success and failures through general experiences". In a related view, Shurts (2004) affirmed that problem-solving ability such as positive and encouraging words that couples say to each other will increase marital happiness and stability. This means that using such words like "my dear", "beloved", "sweet heart" and "it will be all right" among other supportive words by couples may increase their chances of having a harmonious and peaceful home. In this study, problem solving ability is defined as the ability of married individuals to apply maturity, respect, love, understanding and wisdom acquired in education and care in dealing with their marital problems so as to create space for marital satisfaction. Education is important in the life of married individuals because the level of education one acquired can be manifested in an individual's way of life, comportment, conversation, reasoning and the attitudes towards one another. Human beings as social animals interact with one another. In their interactions, problems resulting from misunderstandings often arise. It is therefore expected that as rational beings, humans should be able to work out possible ways to solve or tackle these problems as they arise. Problem-solving ability is a veritable tool in creating mutual interpersonal relationship among individuals. Problem in the views of Loveth (2002) "is a situation for which the individual who confronts it has no algorithm that will guarantee a solution". Stressing further, the author stated that an individual's knowledge must be put together in a new way to solve the problem. Problem-solving is defined as finding a way where no way is known, off-hand, out of a difficult situation or around an obstacle. This calls for developing a problem-solving ability by individuals. In marriage, problem-solving ability is a process whereby couples are able to settle their marital problems through positive reactions to each other's view (Mitchell, 2012).The author reiterated that couples should be able to enter into positive communications, make positive decisions, share resolutions, organize their plans and carry them out and share their success and failures through general experiences.

Inability of couple to apply problem solving ability in their marriages to achieve marital satisfaction may be attributed to level of education among the individuals. Then one begins to wonder if level of education of couple has anything to do with the level of their understanding or if the couple's level of education improves their marital understanding or not.

Since level of education could also enhance understanding of each other and society one begins to suspect if level of education has anything to do with marital satisfaction in a certain marital relationship. According to Keirsten (2010), defined educational level as the highest level of education one has achieved. Level of education is the level of education you have actually attained educationally as defined in Michael West Dictionary. Operationally level of education is defined as the a limit, stage and height of education one have actually attained, for example from Nursery school to primary, from primary school to secondary school and from secondary to higher institution. 
In terms of level of education, Heaton (2002) opined that a higher education level could potentially predict marital satisfaction. Buttressing further, the author stated that educated families could handle and manage issues especially those debilitating ones in the family. The question raised by Tucker and O'Grady (2010) about whether differences in education level can predict marital dissatisfaction is also of note since Heaton (2002) postulated that educated families could be more informed of the techniques involved in maintaining harmonious marriage than their counterparts who are less educated. Ajanssen (2008) stated that highly educated women had higher rate of unstable marriages, using the national survey of family growth data in Croatia. Alder (2010) on the study of marital satisfaction in relation to education, reported that both society and the individuals benefit when educated couples form strong marriages, as those unions frequently lead to less involvement in crime and other detrimental activities by spouses and offspring. Given that education level generally increases as age increases (e.g. people do not decrease in education level) and that educational level is positively correlated with marital satisfaction, it seems reasonable to hypothesize that educated family would be more positively correlated with marital satisfaction.

On the contrary, Jose and Alfons (2007) reported that couples with higher education have more stressors within their marriages that affect their marital satisfaction, as well as whom they choose to marry.Tucker and O'Grady (2010), asserted that married couples with differing levels of education might be less satisfied with their marriages if the woman of the dyad is the one with a higher level of education. From the foregoing, it could be deduced that there are diverse opinions from the various authors as cited in this study regarding education as a correlates of marital satisfaction. This is as a result of the fact that while some scholars are of the opinion that educated families have more information regarding problem solving abilities on marital problem for marital satisfaction, some have different views which is that families with higher education find it difficult to handle their marital problem which leads to marital problems. The extent to which this is true of the sample of this study is yet to be verified hence the study will try to explore the issue. People's behaviours or actions are often placed side by side their educational level. An educated person is often expected to behave or conduct oneself in a certain moderate manner thus there are high expectations on educated individuals to have higher understanding of issues and situations as well as have better approach in handling these issues anytime and any day. Being educated means basically the ability to read and write as a result of training or education acquired. Being educated in the world today means more than being able to read and write, it also includes according to UNESCO, "the ability to identify, understand, interpret, create, communicate and compute, using printed and written materials associated with varying contexts". Consequently, "an educated person is an individual who possesses the ability to identify, understand, interpret, create, communicate and compute, using printed and written materials associated with varying contexts".

Worthy of note is the fact that the level of education among individuals may differ accordingly and can as well predict greater exhibition of greater success in various areas of life like career, relationships or marriages. Level of education refers to the years of formal instruction received and successfully completed, usually based on passing formal examinations. (May, Alkman 2003). According to International Standard Classification of Education (2011), level of education refers to achievement of the learning objectives of that level, typically validated through the assessment of acquired knowledge, skills and competencies. Operationally, level of education can be defined as the knowledge, skills and competencies acquired educationally through formal training and learning in the school environment that will allow the individual to get certificate of completion. Heaton (2002) opined that a higher education level could potentially predict marital satisfaction. Buttressing this fact further, the author averred that educated families can handle and manage issues especially, those debilitating ones. The question raised by Tucker and O'Grady (2010) about whether differences in level 
of education, can predict marital dissatisfaction is also of note since the authors postulated that educated families could be informed of the techniques involved in maintaining harmonious marriage than their counterparts who are less educated. Bradbury, Fincham, and Beach (2000) continued in a similar line of thought on marital satisfaction in relation to education and submitted that both the society and the individual benefit when couples form strong marriages. This is because such unions frequently lead to less involvement in crime and other detrimental activities by spouses and offsprings. Given that educational level generally increases as age increases (e.g. people do not decrease in educational level) and that age is positively correlated with marital satisfaction, it seems reasonable to state that educated family would be positively correlated with marital satisfaction as well (Alder, 2010).

Contrary to the above position, Jose and Alfons (2007) posited that couples with higher education have more stresses within their marriages that affect their marital satisfaction. In their own views, Tucker and O'Grady (2010) asserted that married couples with differing levels of education may be less satisfied with their marriages if the woman is the one with a higher level of education. Some scholars are of the opinion that educated individuals have more information regarding problem solving abilities for marital satisfaction. Contrarily, some scholars are of the view that the higher educated families are, the more complex and difficult it is for them to handle their marital problems hence, leading to unsuspected marital problems.

In this study, educated individuals could be seen as those individuals who due to the education or the training they have received are able to read and write and are also equipped with the ability to identify, understand, interpret and communicate effectively in order to come up with prompt solutions to the very many problems in the family and outside the family for peaceful coexistence with one another. On the other hand, non educated individuals are those individuals who did not receive any or sufficient education or training and as a result are unable to read and write and be equipped to identify, understand, interpret and communicate effectively in order to come up with prompt solutions to the very many problems in the family and outside the family for peaceful coexistence with one another. The above explanations imply that among the very many essential abilities or skills, education affords any individual the problem-solving ability. This ability enables one to derive satisfaction from any activity, engagement or endeavour like; career and marriage among others. This also means that if one is not educated both male and female (gender), one may not be equipped with the necessary abilities or skills of problem-solving and, thus will not be able to derive maximum satisfaction from any endeavour like career or marriage.

\section{CONCEPT OF GENDER}

Gender is a complex concept that means different things to people of varying culture and professional background. It can be seen as a cross-cutting socio-cultural variable. Gender involves a range of characteristics pertaining to, and differentiating between masculinity and femininity (Skirley, 2008). According to Brown (2010), gender is a social construct that describes and defines the roles men and women play in society. Okeke (2008) refers to gender as the socially and culturally constructed characteristics and roles which are ascribed to males and females in the society. According to the author, these ascribed roles and responsibilities created in the families, societies and cultures include the expectations held about the characteristics, aptitudes, and likely behaviour of both men and women. These expectations can change over time and also varies between cultures. In another view, Eze and Nnennaya (2013) describes gender as the roles, relationship, status, expectations, obligations, and the entire notion of what is ascribed by culture to males and females at a 
given point in time. These attributes, opportunities and relationships are socially constructed and are learned through socialization processes. Gender is described as the characteristics between males and females in any society.

Gender is the social and psychological aspects of being female or male, it includes a person's understanding the meaning of his or her own life of being a male or a female (Halperm-Felsha, 2012). Attributes of masculinity and feminity are also considered in talking about gender. Qualities such as assertiveness, bravery, independence, strength, rationality and dominance are attributed to the male gender while the qualities of nurturing, warmth, gentility, emotionality, caring and sensitivity are attributed to female gender (Papalia, Olds and Feldman, 2000). This stereotype creates expectations for the way women and men behave, think, feel about themselves and react or respond to environmental demands. According to (Onyeonoru, 2005), gender refers to the differentiation in roles between and women which is different from sex but constructed by society through socialization. Sex is the physical difference between people's body example boy or girl. Gender which is the behavioural, cultural or psychological traits, it typically associated with one's sex. A person's gender role refers to the way a community defines what it is to be a woman or a man. Each community expects a woman and a man to look, think, feel and act on a certain ways just because they are women or men. In most countries for example, women are expected to prepare food, fetch water and care for children while men are expected to work outside the home to provide for their families and parents and defend them from harm.

Gender is therefore not synonymous with sex. While sex is the biological composition of man and woman, gender refers to those roles and expected behaviours which are socially and culturally ascribed to males and females. In the context of this study, therefore gender can be defined as the characteristic behaviours and psychological attributes expected of an individual on the basis of being born male or female.

From the aforementioned, and deducing from the rate of discrepancies among scholars on the various variables that informed this study as discussed namely; courtship, problem solving and marital satisfaction, it becomes pertinent and imperative to explore courtship and problem-solving abilities as predictors of marital satisfaction among married individuals in South, Nigeria.From experiences and observations, it appears that many families in South East are in disagreement with their spouses presumably because they do not involve themselves in any courtship activities before embarking on marriage. Some during an interview with the researcher reported that they never knew that their spouses could behave in certain disgusting ways. Some of them openly stated that they did not know much about their partners before marriage. This is suspected to account for the incidence of dysfunction, separation, broken homes and even divorce cases among families in this area. In this scenario, the researcher is worried of the fate of children from shattered families and marriages. The problem is that children from broken relationships may become untrained, restive, touts, nuisance, deviants and even criminals constituting threats to the entire society. It is premised on this, that the study explored the correlation among courtship (including length of courtship), problem solving ability and marital satisfaction among married individuals in South East Nigeria. This is more so as marital dissatisfaction leading to separation and divorce has continued unabated in spite of the obvious damaging effects on the children and society among others.

\section{STATEMENT OF THE PROBLEM}

The unity of the society starts from the families. The sustainability and joy of the family lies in the mutual and interpersonal relationship that exists among couples in their respective marital lives. Unfortunately, it appears that many couples in South East struggle to sustain peaceful living while some seem to be giving up to divorce, broken homes and separation thereby creating a shattered marriage. In recent data, according to National Bureau of Statistics, the divorce 
statistics in Nigeria show that $0.2 \%$ of men and $0.3 \%$ of women have ended their marriages. Bureau of statistics (2013), reported that the rate of divorce among Nigeria female youth was as high as $70.9 \%$. This is however worrisome, given that Nigerians are highly secretive in matters of marriage and family, more men and women have shown many be in a merely "ending marital relationship" and not in a marital relationship with satisfaction.

Experience and observation, also show that some spouses never knew that their partners could behave in certain disgusting way such as displaying grievances, aggressiveness, and anger, being insultive and disobedient among others before they married. Some married individuals have left their matrimonial homes to undisclosed places from their spouses for some days while some women reported that their husbands could not satisfy them sexually and could not even provide their material needs. Others stated that their marriages are characterized by quarreling, unhappiness, fighting and mistrust. Some spouses have sustained bruises, fractures and burns from pouring of hot water from their various marriages. These problems are indicate of marital dissatisfaction among married individuals leading to separation, broken homes and even divorce among families in this area. The researcher is worried of what the fate of children from such shattered families and marriages is. The problem is that children from broken marriages and families may become untrained, restive, touts, nuisance, deviants and even criminals constituting threats to their families and the society at large. This may have worsened presumably because spouses may lack problem solving abilities. The researcher is therefore worried about the level of marital satisfaction of married individuals in South East Nigeria and whether such level of satisfaction could be as a result of problem-solving ability of these married individuals in South - East Nigeria. It is in view of these concerns that this study asks, to what extent do problem solving ability predict marital satisfaction among married individuals in the South-East Nigeria?

\section{Purpose of the Study}

The main purpose of the study is to investigate problem solving ability as predictor of marital satisfaction among married individuals in South-East Nigeria. Specifically, the study seek to:

- Ascertain the amount of variation in the marital satisfaction among married individuals that is attributed to problem solving ability.

- Determine the influence of level of education on the variation in the marital satisfaction of married individuals that is attributed to problem solving ability.

- Determine the influence of gender on the variation in the marital satisfaction of married individuals that is attributed to problem solving ability.

\section{Research Question}

- What is the amount of variation in the marital satisfaction among married individuals that will be attributed to problem solving ability.

- What is the influence of level of education on the variation in the marital satisfaction of married individuals that will be attributed to problem solving ability.

- What is the influence of gender on the variation in the marital satisfaction of married individuals that will be attributed to problem solving ability. 


\section{Hypotheses}

The following null hypotheses were formulated to guide the study and tested using regression analysis at 0.05 level of significance

- HO 1: The amount of variation in marital satisfaction of married individuals is not significantly related to problem solving ability

- HO 2: The amount of variation in marital satisfaction of married individuals due to problem solving ability is not significantly dependent on level of education.

- HO 3: The amount of variation in the marital satisfaction of married individuals due to problem solving ability is not significantly dependent on gender.

\section{METHOD}

\section{Design of the Study}

The researcher adopted correlation research design. Correlation design According to Ali (2006) defined correlation research design as the relationship between two variables (dependent and independent variables). Nworgu (2015) also refers to the type of study which seeks to establish the relationship that exists between two or more variables. Also, The design was considered appropriate for this study because the researcher will make use of data collected from a sample population to examine and establish the relationship which courtship and problem-solving (as independent variables) have with marital satisfaction (the dependent variable) among married individuals in South East, Nigeria.

\section{Population of the Study}

The population of the study comprises all the married individuals in the South East. This was estimated to be 10,533 comprising 4,962 males and 5,571 females married individuals (Source: National population commission, 2016). The choice of married individuals was due to the fact that there are a lot of cases separation and divorce among married individuals in South East, Nigeria that lead to marital dissatisfaction.

\section{Sample and Sampling Techniques}

The sample size of the study was 900 married individuals. The researcher adopted multi-stage sampling procedure. Stage one involved classifying the South-East into 5 stages Abia, Anambra, Ebonyi, Enugu and Imo. Three states namely Anambra, Enugu and Imo were randomly sampled from the five states. Stage two involved stratifying the three sample states into senatorial zones respectively. In each of the sampled states, one senatorial zone was randomly using balloting with replacement giving a total of three senatorial zones sampled for the study. Stage three also involved stratifying the three sampled senatorial zones into local government areas. Three local government areas were randomly sampled from each of the sampled senatorial zones giving a total of nine local government areas using balloting with replacement. The researcher in stage four randomly sampled five communities from each of the nine sample local governments giving a total of 45 communities using balloting with replacement. In each of the sampled communities, 20 married individuals were sampled using snowball sampling techniques giving a total of 900 married individuals. 


\section{INSTRUMENT FOR DATA COLLECTION}

Two instruments were used for data collection, namely problem solving ability questionnaire [PSAQ] and marital satisfaction questionnaire [MSQ].

Each of the instruments had two section, section A, which contained demographic variables of the respondents and section $\mathrm{B}$ contained items required for getting information on the variables of interest. In problem solving questionnaire, section A contained demographic variable of the respondents such as state, level of education, sex and other information. Section B contains 20 items that measured problem solving ability. The items were measured on 4 point rating scale of Strongly Agree, Agree, Disagree and Strongly Disagree weighted 4, 3, 2, 1 for positive items respectively and 1, 2, 3, 4 for negative items respectively. In marital satisfaction questionnaire, section A also contained demographic variables of the respondents such as state, level of education, sex and other information that were helpful. Section B contained 30 items that measured marital satisfaction. The items were measured on 4 point rating scale of highly satisfied, Satisfied, Not satisfied and Not very satisfied weighted 4,3,2,1, for positive items respectively and 1,2,3,4,for negative items respectively.

The instruments were subjected to face validation by giving to three experts in guidance and counselling, education psychology and measurement and evaluation, university of Nigeria, Nsukka. The validators were requested to scrutinize the items of the instruments for clarity, appropriateness of the language used, coverage of the items and relevance of the items to the variables under study. The comment made by the validatiors were used to produce a final copy of the instrument for a example reducing of items developing two different instruments, and the making each instrument to have its own demographic data.

To establish the reliability of the instrument, trial-testing procedure was used. The instruments were administered to 20 married individuals [comprising 10 men and 10 women] in five local government area in Abia state, which is outside the study area. The responses of the married individuals were used to determine the reliability co-efficient of the instrument using cronbach alpha statistics. The statistics used for the determination of the internal consistency of the items were polythomously scored. The internal reliability co-efficient of the instruments were found to be MSQ $=0.882$ and PSAQ=0.662.

\section{Method of Data Collection}

The researcher administered the instruments to the respondents with the help of twelve (12) research assistants. Adequate briefing was given to the research assistants on mode of administration and filling of the questionnaire. The use of these research assistants helped to ensure that the actual respondents for whom the instrument was meant for completed them. It helped them to make clarification on items wherever the need arises. This helped to reduce likely errors that may arise in their responses to the different items. For instance, they were assured that they are not involved in any examination and their responses will be treated with confidentiality, and as such, there is no right or wrong answers. The administration and collection of the questionnaire lasted for four days. Though 900 copies were distributed but only 874 copies collected with amount to $97.1 \%$ of return. Twenty six copies were returned on field because the respondents felt that the items were prying into their private life.

\section{METHOD OF DATA ANALYSIS}

The data collected were analyzed using Regression Analysis. The hypotheses were tested using simple linear regression and multi linear regression at $\mathrm{P}<.05$ level of significance. 


\section{Hypothesis One}

$\mathrm{HO}_{2}$ : Problem solving ability will not significantly predict the amount of variation in marital satisfaction of married individuals in South East Nigeria.

Table 1: Simple Linear Regression Analysis of Problem Solving Ability and Marital Satisfaction of Married Individuals in South East Nigeria

\begin{tabular}{|l|c|c|c|c|c|}
\hline \multicolumn{1}{|c|}{ Model } & Sum of Squares & Df & Mean Square & F & Sig. \\
\hline Regression & .008 & 1 & 0.008 & 0.034 & 0.854 \\
\hline Residual & 194.380 & 871 & 0.223 & & \\
\hline Total & 194.387 & 872 & & & \\
\hline
\end{tabular}

$\alpha=0.05$, Sig. $=$ Significant

In order to test the null hypothesis $1\left(\mathrm{HO}_{1}\right)$, a simple linear regression analysis was used. The result as presented in Table 1 shows that the F-ratio of 0.034 obtained was associated with a probability value of 0.854 . This probability value (0.854) was compared with $\mathrm{P}<0.05$ set as the level of significance for testing the hypothesis and was found not to be significant because, they obtained F-ratio (0.854) is greater than 0.05. The null hypothesis which said that problem solving ability does not significantly predict the amount of variation in marital satisfaction of married individuals in South East Nigeria was therefore accepted. The inference drawn was that problem solving ability did not significantly predict the amount of variation in marital satisfaction of married individuals in South East Nigeria.

\section{Hypothesis Two}

$\mathrm{HO}_{2}$ : The amount of variation in marital satisfaction of married individuals in South East Nigeria is not significantly related to problem solving ability influenced by the level of education.

Table 2: Multiple Regression Analysis of Problem Solving Ability, Level of Education and Marital Satisfaction of Married Individuals in South East Nigeria

\begin{tabular}{|l|c|c|c|c|c|}
\hline Model & Sum of Squares & df & Mean Square & F & Sig. \\
\hline Regression & 0.854 & 3 & 0.285 & 1.280 & 0.280 \\
\hline Residual & 193.533 & 870 & 0.222 & & \\
\hline Total & 194.387 & 873 & & & \\
\hline
\end{tabular}

$\alpha=0.05$, Sig. $=$ Significant

In order to test the null hypothesis $2\left(\mathrm{HO}_{2}\right)$, multiple regression analysis was used. The result as presented in Table 2 shows that the F-ratio of 1.280 obtained was associated with a probability value of 0.280 . This probability value (0.280) was compared with $\mathrm{P}<0.05$ set as the level of significance for testing the hypothesis and was found not to be significant because, the obtained F-ratio (0.280) is greater than 0.05 . The null hypothesis which said that the amount of variation in marital satisfaction of married individuals in South East Nigeria is not significantly related to problem solving ability influenced by the level of education was therefore accepted. The inference drawn was that the level of education did not influence problem solving ability to significantly predict the amount of variation in marital satisfaction of married individuals in South East Nigeria.

\section{Hypothesis Three}

$\mathrm{HO}_{3}$ : The amount of variation in marital satisfaction of married individuals in South East Nigeria is not significantly related to problem solving ability influenced by the gender of the respondents. 
Table 3: Multiple Regression Analysis of Problem Solving Ability, Gender and Marital Satisfaction of Married Individuals in South East Nigeria

\begin{tabular}{|l|c|c|c|c|}
\hline \multicolumn{1}{|c|}{ Model } & Sum of Squares & df & Mean Square & F \\
\hline Regression & 0.638 & 3 & 0.213 & 0.955 \\
\hline Residual & 193.749 & 870 & & \\
\hline Total & 194.387 & 873 & & \\
\hline
\end{tabular}

$\alpha=0.05$, Sig. $=$ Significant

In order to test the null hypothesis $3\left(\mathrm{HO}_{3}\right)$, a simple linear regression analysis was used. The result as presented in Table 3 shows that the F-ratio of 0.213 obtained was associated with a probability value of 0.955 . This probability value (0.955) was compared with $\mathrm{P}<0.05$ set as the level of significance for testing the hypothesis and was found not to be significant because, the obtained F-ratio (0.955) is greater than 0.05 . The null hypothesis which said that the amount of variation in marital satisfaction of married individuals in South East Nigeria is not significantly related to problem solving ability influenced by the gender of the respondents was therefore accepted. The inference drawn was that the gender of the respondents did not influence problem solving ability to significantly predict the amount of variation in marital satisfaction of married individuals in South East Nigeria.

Variation in the Marital Satisfaction Attributed to Problem Solving Ability of Married Individuals in South East Nigeria

The findings of this study showed that there was more or less no direct positive relationship between problem solving ability and marital satisfaction. The coefficient of determination indicated that $100 \%$ of the variation in marital satisfaction is attributed to other variables outside problem solving ability. This shows that the amount of contributions to marital satisfaction by problem solving ability was small. Although, there is need for married individual to possess problem solving ability, but from the findings of this study, it has been established that married individuals can be martially satisfied without having problem solving ability since the problem solving ability contribute little or nothing to the marital satisfaction of married individuals. This shows that there may be other variables such as love, patience, wealth, offspring and health can contributed to marital satisfaction of married individuals in South East Nigeria. This implies that having problem solving ability is not a guaranty for marital satisfaction. This finding however differed from the study carried out by Kriegelewicz (2006) on problem-solving strategies and marital satisfaction on married individuals in University of Warsaw Indian, who reported that satisfied couples tend to use constructive problem-solving strategies (dialogue and loyalty). From the views of (Mitchell, 2012), and (Erus, 2016) problem solving ability can only help the couples to overcome the obstacles which they encountered in the past. This would however not translate to marital satisfaction as observed in this present finding.

Influence of Level of Education on the Variation of Marital Satisfaction Attributed to Problem Solving Ability of Married Individuals in South East Nigeria

The result showed that there was a positive in the relationship between problem solving ability and marital satisfaction of married individuals as moderated by level of education of the respondents in South East Nigeria. However, the level of education moderate variation of marital satisfaction attributed to problem solving ability. This mean that level of education of married individual predicts marital satisfaction of married individuals due to problem solving ability but this variation is so small. This show that education is an important variable in our lives, but does not contribute to marital satisfaction of married individuals. This finding agreed to the fact that an educated person is often expected to behave or conduct oneself in a certain moderate manner, but this expectation does not translate in the handling issues relating to marital satisfaction. 
The findings is in contract with the finding of Bradbury, Fincham, and Beach (2000), Heaton (2002), and Tucker and O'Grady (2010) who all pointed out that a higher education level could potentially predict marital satisfaction.

Influence of Gender on Variation of the Marital Satisfaction Attributed to Problem Solving Ability of Married Individuals in South East Nigeria

The result indicates that the moderation of gender on variation of the marital satisfaction attributed to problem solving ability is very low. This inference indicates that the gender of the respondent is not a serious factor in the problem solving ability for predicting the amount of variation in the marital satisfaction married individuals in South East. This indicates that there may be other variable outside gender that can attribute to marital satisfaction of married individuals in South East Nigeria. The finding of this study does agree with the findings of Brawn (2010) who reported that gender as a social construct in the marriage does not predict much to marital satisfaction.

\section{CONCLUSIONS}

Based on the findings of this study, it was concluded that there was a weak direct positive relationship between problem solving ability and marital satisfaction. The level of education of the married individuals and their gender also help increased the relationship that exists between problem solving ability and marital satisfaction.

\section{EDUCATIONAL IMPLICATION OF THE STUDY}

The findings of this study have far-reaching implications. This result indicates that there is dire need for trained individuals like marriage counsellors, pastors and churches to organize programmes that would help to educate married individuals, and would be couples before they get married. With this done, proper knowledge of what spousal relationship entails would be acquired and cases of marital discords would be reduce while marital satisfaction would increase.

There is a positive relationship between problem solving ability and marital satisfaction. This indicates that problem solving ability alone cannot assure marital satisfaction of the married individuals as other factors come into play. By constantly exposed to marriage counselling, teaching, seminars, workshop on other issues that tend to threaten marital satisfaction can be discussed which will create room for marital satisfaction. The findings of this study also revealed that there is a high instance of marital satisfaction in South East Nigeria. This is an indication that problem solving ability to some extent can guarantee marital satisfaction. Although, other factors may be considered in a bid to ensure marital satisfaction in some home.

\section{RECOMMENDATIONS}

Based on the findings and implications of this study, the following recommendations are made.

- The finding of the study showed that there is a positive and significant relationship between problem solving ability and marital satisfaction of married individuals, it is therefore recommended that married individuals should be encouraged by marriage counsellors to develop a problem solving ability skills that will facilitate marital satisfaction.

- Marriage counsellors should also collaborate with churches, government, individuals and non- governmental organisations [NGO] in organizing periodic seminars and workshops to train and educate both intending couples and married individuals on how to raise happy peaceful families. 


\section{LIMITATIONS OF THE STUDY}

Although this study was successfully completed, it had limitation which may have impaired the generalizability of findings. The study was limited only to three out of five South East state in Nigeria, which include Anambra, Enugu and Imo states, since the study covered only three states of the South East Nigeria, generalizability of findings would have been affected. Thus, further study cutting across all parts of South East is necessary. However, the randomization in sampling is ensured that every married individual in the geographical area has equal opportunity of partaking in the study. Other limitations was as a result of the respondents feeling that the items in the instruments were prying into their private lives and at such became bias in responding to the items. This is what we call social desirable factor of every individual to portray themselves as good.

\section{REFERENCES}

1. Ajanssen, (2008).National survey of family growth data of Zagreh, Ryeka, Osijek and split in Croatia.

2. Alder, E. S. (2010). Age, Education level, and length of courtship in relation to marital satisfaction (Master's thesis, Pacific University).Retrieved from: http://commons.pacificu.edu/spp /145.

3. Ali, A. (2006). Conducting research in education and social sciences. Enugu: Tashiwa, Networks Ltd.

4. Bagarozi, D. A., Bagarozi; J. I., Anderson, S. A., \&Pollance, L. (2004). Premarital education and training sequence (PETS). A 3-year follow-up of an experimental study.Journal of Counselling and Development, 63 (8): 91 - 100.

5. Bradbury, T. N., Fincham, F. D., \& Beach, S. R. H. (2000). Research on the nature anddeterminants of marital satisfaction: A decade in review. Journal of Marriage andDissertation Abstracts International, 67(4-B), 2279.

6. Brown, P. B. (2010). Relationship education: Helping couples live happy, full lives. The Bulleting of the Australian Psychological Society, 24 (3), $14-16$.

7. Bureau of Statistics (2013).Nigeria-general household survey panel 2012-2013. Wave 2.

8. Charisma Test (2006).Charisma research-journal of counseling and development. 83 (1), 58-68.

9. Dewald, N. H. (2010). Human performance on insight problem solving.Journal of Problem Solving, 3 (2), 52 - 92.

10. Egbo, C. B. (2003). The impact of family background and early marital factors on marital disruption.Journal of Family Issues, $12(1), 22-42$.

11. Emily, A.S. \& Todd, K.S. (2015).Marital Satisfaction. Retrieved from: DOI:http://dx.doi .org/10.4135/9781412956253.n323.

12. Erus A. (2016) Perceived problem solving skills of married individuals predicting self-efficacy beliefs towards marriage. Journal of Applied Sciences 10(8), 682 - 687.

13. Erus, S. M. (2016). Perceived problem solving skills of married couples predicting self-efficacy beliefs towards their marriage.A Master's Thesis of Marmara University.

14. Eze, G. N. \&Nnennaya, K. (2013). Strategies for closing the gender gap in science and technology (SRT) classrooms in Nigeria secondary schools: Teachers perception of gender mainstreaming. Journal of Educational and Social Research.MCSER publisher.Rome, Italy. 3 (1), 9 - 16.

15. Galundia, Ruchi, and Vinita Sharma."A Comparative Study on the Marital Satisfaction among Fertile and Infertile Couples. "International Journal of Educational Science and Research (IJESR) 8. 6, Dec 2018, 23-28

16. Gottman, H. (2004). The Bane of Matrimonial Relationship and Marital Stability. Norwich City: Thompson Press. 
17. Haviland, W. A. (2011). Cultural Anthropology: The Human Challenge [13th ed.]. Monktan: Cengage Learning Publication.

18. Halpern-felsher, B. (2012). Adolescent decision making. An overview. New York: McGraw Press.

19. Heaton, T. B. (2002). Factors contributing to increasing marital stability in the United States.Journal of Family Issues, 23(3), $145-157$.

20. Inigiabuna, T. E. (2016). National population commission, population and development in Nigeria-Africa. Online Journal.

21. International Standard Classification of Education (ISCED) (2011). Educational, Scientific and Cultural Organization, Retrieved from www.un.org/UNESCO.2012.Jose, O., \&Alfons, V. (2007). Do demographics affect marital satisfaction? Journal of Family Issues, 23(3), 392-409. doi: 10.1177/0192513X02023003004

22. Jose, O., \&Alfons, V. (2007). Do demographics affect marital satisfaction? Journal of Family Issues, 23(3), 392-409. doi: $10.1177 / 0192513 X 02023003004$

23. Kang, T. \&Taswal, S. (2009). Marital stability as a correlate of parenting. Student Home Communication Science, $3(1)$, $39-$ 42.

24. Kaslow, F. W. (2002). Portrayal of the Healthy Couple. Psychiatric Clinic of North America, 5 (7), 519 - 527.Kang, T. \&Taswal, S. (2009). Marital stability as a correlate of parenting. Student Home Communication Science, 3(1), 39 - 42.

25. Keirsten, S. (2010). Medical Anthropology International Health Journal, vol 6, pg $101-103 . *$

26. Loveth, M. C. (2002). Problem Solving. In Medin, D. (Ed). Stephen's handbook of experimental psychology, 2, 317 - 362. New York: Wiley.

27. Maciver, J.E. \&Dimkpa, D. I. (2012). Factors influencing marital stability. Mediterranean Journal of Social Sciences, 3 (1), $33-43$.

28. Maduka (2006). Comparison of Outcome Between Teenage and Older Primigravidae in Jos University Teaching Hospital, Jos, North-Central Nigeria. Article in annals of African Medicine 5(2).

29. May, S., Alkman, S. (2003). Indigenous education: Addressing current issues and developments comparative education 39(2): 139-145. doi:10:1080/03050060302549.JsTOR3099875.

30. Mba, C. S. (2008). A Handbook on marriage; Book two. Owerri. Jeybros Group (Nig) Ltd. (Printing Division).

31. Mitchell, J. K. (2012). Marital dining practices: Affecting change in marital satisfaction through marital self-efficacy. Unpublished PhD Thesis, University of George Fox.

32. Mulder M. B. (2009). Tradeoffs and sexual conflict over women's fertility preferences in Mpimbwe. American. Journal of Human Biology. doi:10.1002/ajhb.2008.

33. Muthukrishnan, A., B. Natarajan, and K. Gomathi Sankar."Relationship of Customer Service Satisfaction with Financial Investor's Marital Status and Family Type at General Insurance Corporation of India."International Journal of Sales \& Marketing Management Research and Development (IJSMMRD) 7. 4, Aug 2017, 19-26

34. National Bureau of Statistics (2018). Statistical Report on Women and Men in Nigeria. 20, 8, 3, 14, $38,5574$.

35. Njoku, T. B. (2009). Premarital Predictors of Marital Quality and Stability: Family Relations. 4 (3), 228 - 237.

36. Nwobi, P. C. (2015). Personal Back group and environmental factors influencing materials adjustment among Anambra State couples Implication of married/family counselling unpublished Ph.D. Thesis, Department of Educational foundation, University of Nigeria. 
37. Nworgu, B.G. (2015). Educational research. Basic issues and methodology: (third edition) Nsukka: University Trust Publishers.

38. Okeke, E. (2008). Clarification and analysis of gender concepts, gender STM Education focus on Research, Reproductive Health Education and Gender Sensitive Classroom. Opara and Nneka (Eds). STAN, 2 (5) ISSN: 2222 - 1719, vol. 3 (15).

39. Onyeonori, I. P. (2005). Industrial Sociology, An African perspective. Ibadan: Samland printers.

40. Oparaugo, B. N. (2010). Igbo Traditional Marriage Rite and the Roman Ordo celebrandimatrimonium of 2000: Roma pontiticiauniversiteGregoriana. Vol. 21, Issue 2, pages $163-183$, ISSN.

41. Papalia, D.E; Olds, S.W \& Feldman, R.D. (2000). A Child's World Infancy through adolescence. New York: McGraw Hill Company Inc.

42. Radhika, P., and K B Glory."Shashi Deshpande's "Strangers to Ourselves "As a Novel of Complex Inexplicable Marital Relationships". "International Journal of English and Literature (IJEL) 8. 3, Jun 2018, 123-126

43. Shurts, W. M. (2004). The relationships among marital messages received, marital attitudes, relationship self-efficacy and wellness among never married traditional aged undergraduate students. Unpublished PhD Thesis, University of North Carolina.

44. Skirley, H. F. (2008). The Hazards of Being Male: Surviving the Myth of Masculine Privilege. Salinas: Wellness and Institute.

45. Subbo (2006). The Conceptualisation of Gends African. Journal of Environmental Science and Technology. 2(10), 318 - 325.

46. Sunil, P. (2011). Five most primary functions of a family. Retrieved August 6, 2012 from http//www.preservearticles.com./---5most-primary-functions-of-a-family.html.

47. Tucker, M. W. \& O'Grady, K. E. (2010). Effects of physical attractiveness, intelligence, age at marriage and cohabitation on the perception of marital satisfaction. Journal of Sex and Marital Therapy. 33, pg. $255-269$.

48. Wallance, R. I. \& Clark, S. G. (2014). Convergent evolution in the interest of integrative problem solving connecting the policy sciences and interdisciplinary studies: Issues in interdisciplinary studies, $134-169$.

49. Weger J. R. (2005). Disconfirming communication and self-verification in marriage. 22: 19 - 31 . 